\title{
Growth and antioxidant system responses of maize (Zea mays L.) seedling to different concentration of pyrene in a controlled environment
}

\author{
Mahdieh HOUSHANI ${ }^{1}$, Seyed Yahya SALEHI-LISAR ${ }_{-}^{* 1}$, Ali MOVAFEGHI ${ }^{1}$, Ruhollah MOTAFAKKERAZAD ${ }^{1}$ \\ Received September 19, 2017; accepted February 16, 2019. \\ Delo je prispelo 19. septembra 2017, sprejeto 16. februarja 2019.
}

\begin{abstract}
Polycyclic aromatic hydrocarbons (PAHs) are a class of organic pollutants effecting different aspects of plants physiology. To assess the physiological responses of plants to PAHs, maize (Zea mays) was treated with 25, 50, 75, and 100 ppm of pyrene and after 21 days, the activity of some antioxidant enzymes, malondialdehyde (MDA), total flavonoid, total anthocyanin, and soluble sugar contents were measured in shoots and roots of plants. Pyrene led to increase MDA content as well as CAT, POD, and SOD activities. Increase in pyrene concentration reduced all studied growth variables and significantly increased photosynthetic pigments contents of plants. Soluble sugar content was significantly higher in the shoot, while that was reduced in the roots through increasing of pyrene concentration $(p<0.05)$. Also, the increase of pyrene concentration decreased total flavonoid content compared to anthocyanin content. In conclusion, these findings supported the hypothesis that pyrene toxicity induces oxidative stress in the maize plant and it also increases the antioxidant systems in order to moderating stress condition. However, the antioxidant system of maize was not strong enough to eliminate all produced ROS at high concentrations, thus this caused oxidative damage to the plant and decreased its growth variables.
\end{abstract}

Key words: PAHs; physiological responses; pollution; toxicity
IZVLEČEK

\section{RASTNI IN ANTIOKSIDACIJSKI ODZIV SEJANK KORUZE (Zea mays L.) NA RAZLIČNE KONCENTRACIJE PIRENA V NADZOROVANIH RAZMERAH}

Policiklični aromatski ogljikovodiki (PAHs) so organska onesnažila, ki vplivajo na različne fiziološke procese $\mathrm{v}$ rastlinah. Za ovrednotenje fiziološkega odziva koruze na PAH-e so bile njene sejanke tretirane s 25, 50, 75, in $100 \mathrm{ppm}$ pirena, po 21 dneh so bile izmerjene $\mathrm{v}$ koreninah in poganjkih aktivnost nekaterih antioksidacijskih encimov, vsebnost malondialdehida (MDA), celokupnih flavonoidov, antocianinov in topnih sladkorjev. Piren je povečal vsebnost MDA kot tudi aktivnosti CAT, POD in SOD. Povečanje koncentracije pirena je zmanjšalo vse merjene rastne parametre in povečalo vsebnost fotosinteznih barvil $\mathrm{v}$ rastlinah. Vsebnost topnih sladkorjev je bila s povečanjem koncentracije pirena značilno večja $\mathrm{v}$ poganjkih in manjša $\mathrm{v}$ koreninah $(p<0.05)$. Povečanje koncentracije pirena je zmanjšalo vsebnost celokupnih flavonoidov $\mathrm{v}$ primerjavi $\mathrm{z}$ antocianini. Zaključimo lahko, da toksičnost pirena inducira $\mathrm{v}$ rastlinah koruze oksidacijski stres in poveča odziv antioksidacijskega sistema na stresne razmere. Kljub temu odziv antioksidacijskega sistema koruze ni zadoščal za preprečitev tvorbe reaktivnih zvrsti kisika $\mathrm{v}$ večjih koncentracijah, kar je povzročilo oksidativne poškodbe $\mathrm{v}$ rastlinah in zmanšalo njihovo rast.

Ključne besede: PAH-i; fiziološki odziv; onesnaženje; toksičnost

\section{INTRODUCTION}

Polycyclic aromatic hydrocarbons (PAHs) are made up of only carbon and hydrogen (Gong et al., 2007) and comprised of two or more fused benzene cycles (Watts et al., 2006; Li et al., 2014). PAHs include a large and heterogeneous group of organic contaminants that are mainly formed and emitted because of the incomplete combustion of organic materials (Lundstedt, 2003). PAHs are divided into two groups including low molecular mass (LMM) compounds containing 2-3 rings and high molecular mass (HMM) compounds

1 Department of Plant Sciences, Faculty of Natural Sciences, University of Tabriz, Tabriz, Iran; *corresponding author: y_salehi@tabrizu.ac.ir 
containing 4-7 rings (Wilson \& Jobes, 1993). Pyrene is one of the high molecular mass PAH which is made of four benzene rings and thus it is determined as one of the important pollutants listed in the Environmental Protection Agency (Khan et al., 2008). Some PAHs are toxic to living organisms and their mutagenic and carcinogenic effects are well known. Hence, their fate and transport in the environment is of worldwide attention (Fuxing et al., 2010).

Plants can uptake PAHs through roots and leaves (Gao \& Zhu, 2004; Collins et al., 2006), and subsequently can transfer them into food chains (Hung \& Mackay, 1997). A number of factors such as concentration and physicochemical properties of the compound, soil type, temperature, plant species and stage of ontogenesis, and lipid content of plants can influence the rate of PAHs uptake by plants (Binet et al., 2000). Indeed, all stages of plant growth can be affected by PAHs from germination to production (Tomar \& Jajoo, 2014). PAHs also have harmful effect on plants in terms of decrease in photosynthesis and respiration, changes in enzyme activities, photosynthetic pigments content (Alkio et al., 2005), and injury to membranes by lipid oxidation (Branquinho et al., 1997; Chiang et al., 1996). Previously, some researchers investigated the effects of PAHs on maize plants (Kummerova et al., 2013; Dupuy et al., 2015; Liao et al., 2015) and this plant was introduced as a good choice for remediation of soil contaminated with PAHs (Liao et al., 2015; Kosnar et al., 2018). However, while the negative effects of PAHs on the plants growth and development is well known, but the all aspects of those effects on plants, and the precise mechanisms of plants response to PAHs toxicity is not completely clear and still remaining ambiguous. Accordingly, in this study, the effects of the different concentrations of pyrene as one of the abundant PAHs in the environment (Wilcke, 2000; Xu et al., 2007) on the growth of maize (Zea mays L.) were studied. Moreover, the evaluation of the biochemical and physiological responses of plants to pyrene toxicity was another aim of this study.

\section{MATERIALS AND METHODS}

\subsection{The treatment}

In order to prepare different concentrations of pyrene $(25,50,75$ and, $100 \mathrm{ppm})$, the appropriate amount of pyrene for each treatments were dissolved in ethanol. Then, the solutions were sprayed on sterile perlite in pots. Treated perlite was used for plant cultivation after evaporation of ethanol for $72 \mathrm{~h}$.

\subsection{Experimental design}

Experiments were conducted as pot culture of plants under controlled conditions using a completely randomized design (CRD) with three replications for each treatment.

\subsection{Plant culture}

The seeds of maize (Zea mays L. var. single crosses 704) were obtained of the East Azerbaijan Research and Education Centre for Agriculture and Natural Resources (Tabriz, Iran) and stored at $4{ }^{\circ} \mathrm{C}$ until cultivation. Appropriate numbers of seeds were selected based on their vigor and uniformity, disinfected using $1 \%(\mathrm{v} / \mathrm{v})$ sodium-hypochlorite solution for 5 minutes, and sufficiently washed using sterile distilled water. Then, the sterilized seeds were planted in uncontaminated (control) and pyrene-contained perlite. After 3 days, all germinated seeds were transferred to growth chambers with controlled conditions $\left(25-30{ }^{\circ} \mathrm{C}, 16 / 8 \mathrm{~h}\right.$ light/dark photoperiod, light intensity of $75 \mu \mathrm{mol} \mathrm{m} \mathrm{m}^{-2} \mathrm{~s}^{-1}$ provided by common day light fluorescent lamps, and relative humidity of $60 \%$ ) for 3 weeks. The water content of the pots was adjusted to $100 \%$ field capacity every two days using sterile distilled water. After 4 and 10 days, the water of pots was replaced with $50 \%$ and $100 \%$ Hoagland solution, respectively.

\subsection{Harvesting of plants and assays}

The cultivation period of plants was 21 days when the PAHs toxicity symptoms such as chlorosis, necrosis, and reduced leaf size were observed in plants. Biochemical and physiological assays were performed using fresh samples before the harvesting of plants. After the estimation of shoot height and root length, the harvested plants were divided into the roots and shoots. The samples were sufficiently washed with water, immediately dried on the towel paper, and transferred to $70{ }^{\circ} \mathrm{C}$ after determining of the fresh mass. The dry mass of samples was measured after $72 \mathrm{~h}$.

\subsection{Measurement of photosynthetic pigments content}

Photosynthetic pigments content (chlorophyll a, b, total chlorophyll, and total carotenoids) was measured according to the method of Hartmut (1987). Briefly, a quantity of $0.1 \mathrm{~g}$ of fresh leaf samples was homogenized with $5 \mathrm{ml}$ of acetone using a mortar and pestle on ice bath. Homogenates were filtered using a number 42 Whatman filter paper and the absorbance of extracts was recorded at 645, 663, and $470 \mathrm{~nm}$ by Spectrophotometer (Analytic Jena, Specol 1500, Germany). 


\subsection{Measurement of total protein content and antioxidant enzyme assays}

An amount of $0.1 \mathrm{~g}$ of samples was homogenized in icecold phosphate- buffered solution (PBS, $50 \mathrm{mM}$, $\mathrm{pH}=7$ ) using mortar and pestle. Homogenates were centrifuged at $10000 \mathrm{~g}$ for $10 \mathrm{~min}$ at $4{ }^{\circ} \mathrm{C}$. The supernatants were used immediately for determination of the total soluble protein content (Bradford, 1976) as well as the activities of superoxide dismutase (SOD), peroxidase (POD), and catalase (CAT).

SOD activity was evaluated by determination of nitroblue-tetrazolium (NBT) photoreduction inhibition by extracts (Winterbourn et al., 1976). The reaction mixture $\mathrm{pH}(3 \mathrm{ml})$ contained $2.7 \mathrm{ml}$ sodium phosphate solution $(1 \mathrm{M}, \mathrm{pH}=7.8), 100 \mu \mathrm{l} \mathrm{NBT}(1.5 \mathrm{mM}), \mathrm{NaCN}$ $(0.3 \mathrm{mM})$ EDTA $(1 \mathrm{M}), 50 \mu \mathrm{l}$ of riboflavin $(0.12 \mathrm{mM})$ and $50 \mu \mathrm{l}$ of enzyme extract. The mixtures were illuminated at light intensity of $75 \mu \mathrm{mol} \mathrm{m} \mathrm{s}^{-1}$ for 12 minutes and the absorbance of the solutions was recorded at $560 \mathrm{~nm}$. The amount of the enzyme causing $50 \%$ protection of NBT photoreduction was considered as one unit and SOD activity expressed as $\mathrm{U} \mathrm{mg}^{-1}$ protein.

The activity of POD was determined by recording the increase in absorbance at $470 \mathrm{~nm}$ during polymerization of guaiacol to tetraguaiacol for 3 minutes (Obinger et al., 1997). The reaction mixture $(1 \mathrm{ml})$ encompassed $300 \mu \mathrm{l}$ of guaiacol $(4 \mathrm{mM}), 350 \mu \mathrm{l}$ of phosphate buffer $(10 \mathrm{mM}, \mathrm{pH}=7), 300 \mu \mathrm{l}$ of $\mathrm{H}_{2} \mathrm{O}_{2}(50 \mathrm{mM})$ and $50 \mu \mathrm{l}$ of enzyme extract. The reaction was initiated by adding $\mathrm{H}_{2} \mathrm{O}_{2}$ to reaction mixture and POD specific activity was calculated using the extinction coefficient of $26.6 \mathrm{mM}^{-1}$ $\mathrm{cm}^{-1}$ for guaiacol. One unit of POD activity was considered as the enzyme amount capable of oxidizing $1 \mu \mathrm{M}$ guaiacol to tetraguaiacol per minute and POD activity expressed as $\mathrm{U} \mathrm{mg}^{-1}$ protein.

CAT activity was assayed according to the methods of Chance and Maehly (1955). The activity of CAT was measured at $240 \mathrm{~nm}$ by following the decomposition of $\mathrm{H}_{2} \mathrm{O}_{2}$ for $3 \mathrm{~min}$. The reaction mixture contained $2.5 \mathrm{ml}$ potassium phosphate buffer $(50 \mathrm{mM}, \mathrm{pH}=7), 1 \mathrm{ml}$ $\mathrm{H}_{2} \mathrm{O}_{2}(10 \mathrm{mM})$ and $500 \mu \mathrm{l}$ of enzyme extract. CAT specific activity (expressing as $\mathrm{U} \mathrm{mg}^{-1}$ protein) was calculated using the extinction coefficient of $27 \mathrm{M}^{-1} \mathrm{~cm}^{-1}$ for $\mathrm{H}_{2} \mathrm{O}_{2}$ and one unit of enzyme activity was considered as the amount of enzyme necessary for the reduction of $1 \mu \mathrm{M} \mathrm{H}_{2} \mathrm{O}_{2}$ per minute.

\subsection{Measurement of malondialdehyde content (MDA)}

Malondialdehyde (MDA) content measured by a method described by Boominathan and Doran (2002). Approximately, $0.1 \mathrm{~g}$ of samples were homogenized with $0.1 \%(\mathrm{~W} / \mathrm{V})$ trichloroacetic acid (TCA, Merck, Germany) and centrifuged for 5 minutes at $10000 \mathrm{~g}$. Then, $0.5 \mathrm{ml}$ of supernatants was mixed with $2 \mathrm{ml}$ of $20 \%$ TCA containing $0.5 \%$ of 2-thiobarbituric acid (Merck, Germany) and heated in hot water at $95{ }^{\circ} \mathrm{C}$ for 30 minutes. Mixtures were immediately transferred to ice bath and then centrifuged at $10000 \mathrm{~g}$ for $15 \mathrm{~min}$. Finally, the absorbance of supernatants was recorded at $532 \mathrm{~nm}$ and MDA concentration were calculated according to a standard curve prepared using 3,1,1,3tetraethoxy propane $(0-100 \mathrm{nM})$ and expressed as $\mu \mathrm{mol}$ $\mathrm{g}^{-1} \mathrm{FM}$.

\subsection{Measurement of total flavonoid and anthocyanin contents}

For measurement of total flavonoid, $0.1 \mathrm{~g}$ of samples was homogenized in methanol $80 \%$ using mortar and pestle. Homogenates were centrifuged at $10000 \mathrm{~g}$ for 5 min and then the $500 \mu \mathrm{l}$ of supernatants, $1.5 \mathrm{ml}$ of $80 \%$ methanol, $100 \mu \mathrm{l}$ of $10 \%$ aluminum chloride solution, $100 \mu \mathrm{l}$ of $1 \mathrm{M}$ potassium acetate, and $2.8 \mathrm{ml}$ of distilled water were added to $500 \mu \mathrm{l}$ of each extract. After 40 minutes, absorbance of the mixture was measured at $415 \mathrm{~nm}$ compared to the control. Quercetin was used for the preparation of calibration curve (20-200 $\left.\mathrm{mg} \mathrm{l}^{-1}\right)$. The total flavonoid content of the extract was reported as milligram quercetin equivalents (QE) $\mathrm{g}^{-1} \mathrm{FM}$ (Chang et al., 2002).

To measure the total anthocyanin content, $0.02 \mathrm{~g}$ of dried plant sample was pulverized with $4 \mathrm{ml}$ of hydrochloric acid containing $1 \%$ methanol in a porcelain mortar. The solution was kept in the refrigerator for 24 hours and then, centrifuged for 10 minutes at $13000 \mathrm{~g}$. The supernatant was removed and absorbance of the extract was measured at 530 and 657 $\mathrm{nm}$ against the control (hydrochloric acid containing $1 \%$ methanol). The anthocyanin content of each extract was calculated using the following equation (Mita et al., 1997).

$\mathrm{A}=\mathrm{A}_{530}-\left(0.25 \times \mathrm{A}_{657}\right)$

Where, $\mathrm{A}$ is absorbance of the solution (subscripts indicate the wavelength at which the absorbance is measured).

\subsection{Measurement of soluble sugar contents}

The soluble sugar content was determined by the phenol-sulfuric acid method (Kochert, 1978). A quantity of $5 \mathrm{ml}$ of ethanol $(70 \%)$ was added to $50 \mathrm{mg}$ of dry sample and incubated in refrigerator for one week. The samples were centrifuged at $10000 \mathrm{~g}$ for 15 minutes at room temperature. Then, $0.5 \mathrm{ml}$ of the plant extract was made to $2 \mathrm{ml}$ with distilled water and then $1 \mathrm{ml}$ of $5 \%$ phenol and $5 \mathrm{ml}$ of concentrated sulfuric acid were added. The mixture was vortexed and incubated for 30 minutes at room temperature. The absorption of solution 
was recorded at $485 \mathrm{~nm}$, and glucose was used to preparation of standard curve. The data were expressed as milligram per gram of plant dry mass and showed as $\mathrm{mg} \mathrm{g}^{-1} \mathrm{DM}$ in the text.

\subsection{Statistical analysis}

All measurements were conducted with three replications and data were reported as mean \pm standard deviation (SD). Data normality was assessed using the Kolmogorov-Smirnov test. The data were analyzed using GLM procedure by SPSS software (Ver.16) and Tukey's multiple range tests was used for mean comparisons at $1 \%$ probability level. SPSS software was used to calculate the correlation coefficient (Pearson) between characteristics. Microsoft excel 2013 software was used for the preparation of figures.

\section{RESULTS}

\subsection{Growth variables}

The results showed that the increase in pyrene concentration significantly reduced all studied growth parameters in comparison to the control $(p<0.05)$ (Table 1). Treatment of plants with $100 \mathrm{ppm}$ of pyrene led to 73.66 and $74 \%$ reduction in the shoot and root length, respectively. In addition, fresh mass of root and shoot decreased to 81 and $77 \%$. Similarly, treatment with 100 ppm of pyrene led to 62 and $61.29 \%$ decrease in shoot and root dry mass in comparison to the control. Although the highest decrease in all growth parameters was shown in plants treated with $100 \mathrm{ppm}$ of pyrene, no significant difference was seen among plants treated with 50, 75, and 100 ppm of pyrene.

Table 1: The effect of concentrations of pyrene on the growth variables of maize

\begin{tabular}{|c|c|c|c|c|c|c|}
\hline Concentration of & Shoot Length & Root Length & Shoot FM & Root FM & Shoot DM & Root DM \\
\hline pyrene (ppm) & $(\mathrm{cm})$ & $(\mathrm{cm})$ & ) $\mathrm{mg}($ & ) $\mathrm{mg}($ & ) $\mathrm{mg}($ & ) $\mathrm{mg}($ \\
\hline 0 & $0.25^{\mathrm{a}} \pm 39.1$ & $1.59^{\mathrm{a}} \pm 28$ & $64.75^{\mathrm{a}} \pm 995$ & $35.45^{\mathrm{a}} \pm 888$ & $16.99^{a} \pm 197$ & $24.03^{\mathrm{a}} \pm 155$ \\
\hline 25 & $1.03^{\mathrm{b}} \pm 26.3$ & $0.03^{\mathrm{b}} \pm 12.6$ & $37.45^{\mathrm{b}} \pm 435$ & $33.4^{\mathrm{b}} \pm 559$ & $3.57^{\mathrm{b}} \pm 93$ & $28.32^{\mathrm{b}} \pm 131$ \\
\hline 50 & $0.06^{\mathrm{c}} \pm 15.2$ & $0.51^{\mathrm{bc}} \pm 9.66$ & $34.16^{\mathrm{c}} \pm 425$ & $37.45^{\mathrm{c}} \pm 239$ & $1.59^{\mathrm{c}} \pm 87.1$ & $3.23^{\mathrm{c}} \pm 94.6$ \\
\hline 75 & $0.21^{\mathrm{d}} \pm 12.6$ & $0.51^{\mathrm{bc}} \pm 9.66$ & $37.26^{\mathrm{d}} \pm 243$ & $17.02^{\mathrm{c}} \pm 222$ & $0.93^{c} \pm 75$ & $1.06^{\mathrm{c}} \pm 63.2$ \\
\hline 100 & $0.26^{\mathrm{e}} \pm 10.3$ & $0.26^{c} \pm 7.27$ & $25.01^{\mathrm{d}} \pm 188$ & $9.86^{\mathrm{c}} \pm 196$ & $1.25^{\mathrm{c}} \pm 74.3$ & $1.58^{\mathrm{c}} \pm 60$ \\
\hline
\end{tabular}

The data represent the mean of three replications \pm SD and similar upper case letters indicates no significant difference at $p<0.05$. DM: Dry Mass, FM: Fresh Mass.

\subsection{Photosynthetic pigments content}

Chlorophyll a content was significantly high in plants treated by 50,75 , and 100 ppm of pyrene in comparison with the control plants and the highest values of chlorophyll a (73.87 and $81.55 \%)$ were observed in plants treated by 75 and 100 ppm, respectively $(p<0.05)$. In contrast, all applied levels of pyrene significantly decreased chlorophyll b content. Such content in the plants treating with $25,50,75$, and 100 ppm of pyrene were decreased to 57.70, 74.27, 70.63, and $73.74 \%$, respectively. Moreover, the highest value of carotenoids $(93.93 \%)$ was observed at $100 \mathrm{ppm}$ of pyrene (Fig. 1). 

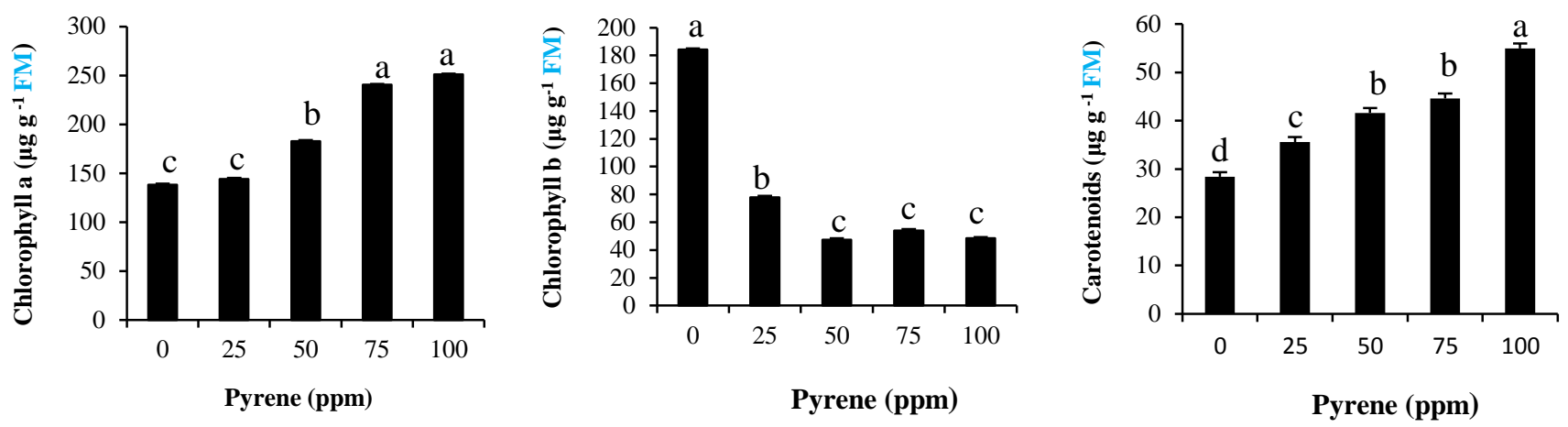

Figure 1: The effect of concentrations of pyrene on photosynthetic pigments contents of maize plants. The data represent the mean of three replications and error bars indicate SD. The same letters above the bars indicate no significant differences $(p<0.05)$.

\subsection{MDA content}

Pyrene had a significant effect on the malondialdehyde content. The MDA content increased by the increasing of pyrene concentrations $(p<0.05)$. The highest amount was measured in plants treated with $100 \mathrm{ppm}$ of pyrene in which MDA contents of shoot and root were 3.6 and 2.33 times higher than its contents in control, respectively (Fig. 2).
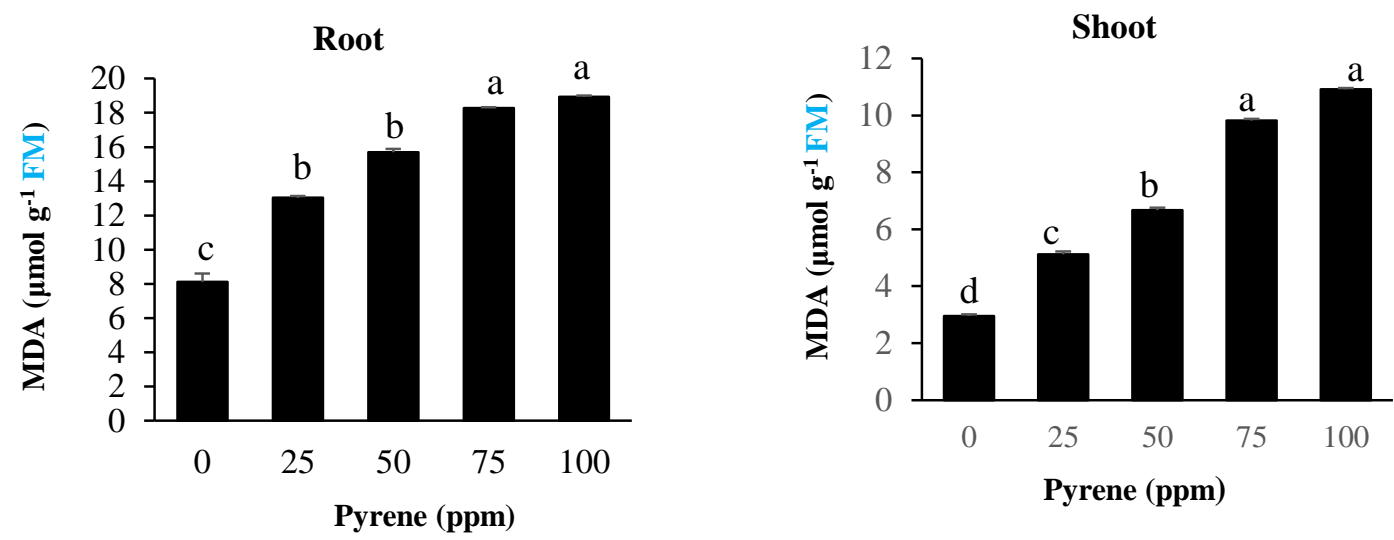

Figure 2: The effect of concentrations of pyrene on malondialdehyde (MDA) content of maize plants. The data represent the mean of three replications and error bars indicate SD. The same letters above the bars indicate no significant differences $(p<0.05)$.

\subsection{Soluble sugars content}

The results showed that pyrene had significant effect on the soluble sugar content in the plant treated $(p<0.05)$. Soluble sugar contents of shoots significantly increased in plants treated with 25 and $50 \mathrm{ppm}$ of pyrene compared with the control $(p<0.05)$. There was no significant difference between controls and plants treated by $75 \mathrm{ppm}$ of pyrene. $100 \mathrm{ppm}$ of pyrene led to significant reduction in shoot soluble sugar content $(p<0.05)$. Regarding root soluble sugar content it was reduced by increasing of pyrene concentration and significantly lower content was observed in plants treated by 50,75 and $100 \mathrm{ppm}$ of pyrene in comparison with the control $(p<0.05)$ (Fig 3). 

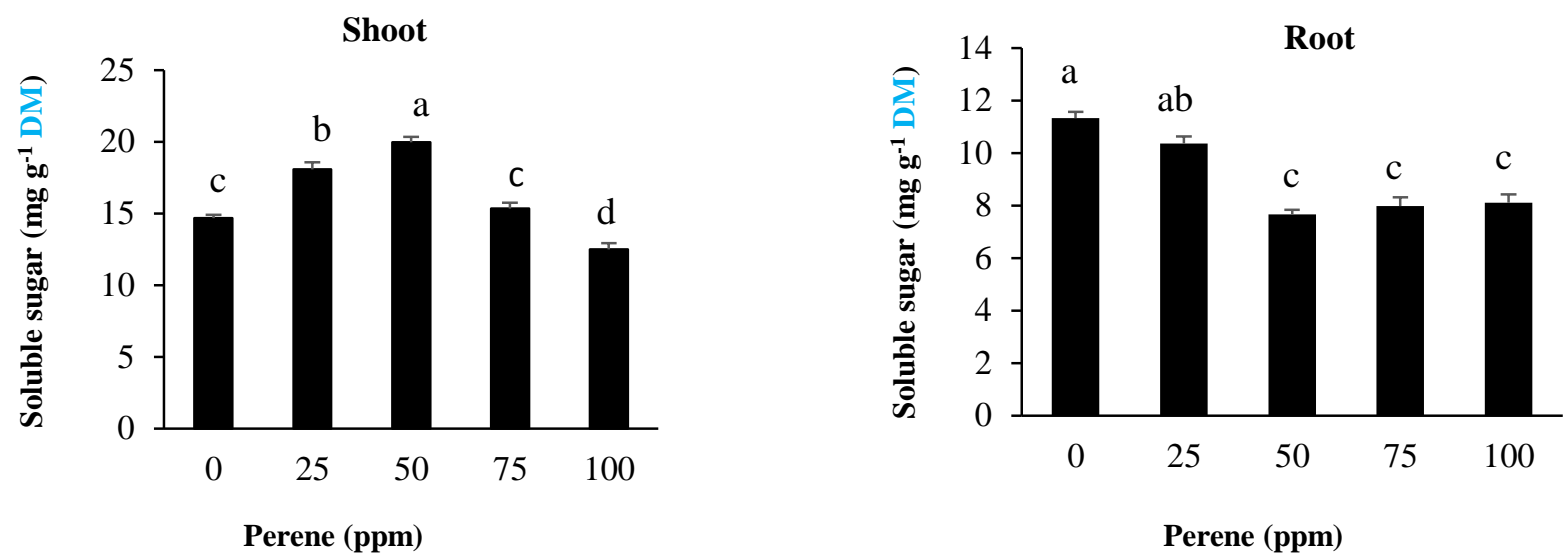

Figure 3: The effect of concentrations of pyrene on soluble sugar contents of maize plants. The data represent the mean of three replications and error bars indicate SD. The same letters above the bars indicate no significant differences $(p<0.05)$.

\subsection{Activity of antioxidant enzymes}

CAT activity significantly decreased in shoots of plants treated by 25 and $50 \mathrm{ppm}$ of pyrene in comparison with the control, but there were no significant difference between plant treated with 75 and $100 \mathrm{ppm}$ of pyrene and control $(p<0.05)$. In the roots, CAT activity in the plants treated by 25,50 , and, $75 \mathrm{ppm}$ of pyrene was increased in comparison with the control (Table 2).

POD activity in shoots of plants treated by different concentrations of pyrene was significantly higher compared to the control and the highest activity (5.75 times) was observed in shoots of plants treated by
$75 \mathrm{ppm}$ of pyrene $(p<0.05)$. Moreover, POD activity in root (especially in plants treated by 25 and $50 \mathrm{ppm}$ of pyrene) was higher than that in control plants, but there was no significant difference in plant treated with 75 and $100 \mathrm{ppm}$ of pyrene and control $(p<0.05)$ (Table 2).

SOD activity in shoot was significantly higher in plants treated with different concentrations of pyrene in comparison to control $(p<0.05)$. Plants treated by 75 ppm of pyrene showed the highest SOD activity in the shoots (2.45 times). Such increase in root was observed in concentration levels of 25 and $50 \mathrm{ppm}$, but a decrease was observed in concentration of $100 \mathrm{ppm}$ in comparison to the control plant.

Table 2: The effect of the concentrations of pyrene on antioxidant enzymes activity ( $\mathrm{U} \mathrm{mg}^{-1}$ protein) in the shoot and root of maize plant

\begin{tabular}{|c|c|c|c|c|c|c|}
\hline \multirow{2}{*}{$\begin{array}{l}\text { pyrene } \\
\text { (ppm) }\end{array}$} & \multicolumn{3}{|c|}{ Root } & \multicolumn{3}{|c|}{ Shoot } \\
\hline & CAT & POD & SOD & CAT & POD & SOD \\
\hline 0 & $0.03^{\mathrm{c}} \pm 0.45$ & $7.69^{c} \pm 80.52$ & $0.6^{b} \pm 47.81$ & $0.002^{\mathrm{a}} \pm 0.183$ & $0.05^{\mathrm{d}} \pm 2.5$ & $0.1^{c} \pm 15.9$ \\
\hline 25 & $0.03^{\mathrm{a}} \pm 0.94$ & $5.98^{\mathrm{ab}} \pm 117.5$ & $0.5^{\mathrm{a}} \pm 102.5$ & $0.01^{\mathrm{b}} \pm 0.133$ & $0.03^{\mathrm{c}} \pm 8.5$ & $0.4^{\mathrm{b}} \pm 22.8$ \\
\hline 50 & $0.01^{\mathrm{b}} \pm 0.75$ & $14.65^{\mathrm{a}} \pm 126.7$ & $0.9^{\mathrm{a}} \pm 97.12$ & $0.001^{\mathrm{b}} \pm 0.130$ & $0.02^{\mathrm{b}} \pm 11.7$ & $0.3^{\mathrm{a}} \pm 36.9$ \\
\hline 75 & $0.002^{\mathrm{bc}} \pm 0.66$ & $10.26^{\mathrm{c}} \pm 72.71$ & $1.2^{\mathrm{b}} \pm 51.61$ & $0.023^{\mathrm{a}} \pm 0.173$ & $0.04^{\mathrm{a}} \pm 14.6$ & $0.9^{\mathrm{a}} \pm 38.9$ \\
\hline 100 & $0.04^{\mathrm{c}} \pm 0.40$ & $9.23^{c} \pm 73.92$ & $0.8^{\mathrm{c}} \pm 25.92$ & $0.004^{\mathrm{a}} \pm 0.193$ & $0.02^{c} \pm 8.1$ & $0.1^{\mathrm{b}} \pm 24.3$ \\
\hline
\end{tabular}

The data represent the mean of three replications \pm SD and similar upper case letters indicates no significant difference at $p<0.05$. CAT: catalase, POD: peroxidase and SOD: superoxide dismutase. 
Growth and antioxidant system responses of maize (Zea mays L.) seedling to ... of pyrene in a controlled environment

\subsection{Total flavonoid and anthocyanin contents}

With increasing pyrene concentration total flavonoids content in shoot and root was significantly reduced compared to control plants $(p<0.05)$. However, there was no significant difference among plants treated with different concentration of pyrene in roots. Treatment of plants with pyrene led to an accumulation of anthocyanins in roots and shoots. The highest anthocyanins content in roots and shoots were observed in plants treated with 75 and $25 \mathrm{ppm}$ of pyrene, respectively (Table 3 ).

Table 3: The effect of the concentrations of pyrene on total flavonoid and anthocyanins content ( $\left.\mathrm{mg} \mathrm{EQ} \mathrm{g}^{-1} \mathrm{FM}\right)$ in the shoot and root of maize plant

\begin{tabular}{cccccc}
\hline \multirow{2}{*}{$\begin{array}{c}\text { pyrene } \\
(\mathrm{ppm})\end{array}$} & \multicolumn{2}{c}{ Root } & & \multicolumn{2}{c}{ Shoot } \\
\cline { 2 - 3 } \cline { 5 - 6 } & Total Flavonoid & Total Anthocyanin & & Total Flavonoid & Total Anthocyanin \\
\hline 0 & $0.001^{\mathrm{a}} \pm 0.270$ & $0.001^{\mathrm{ab}} \pm 1.01$ & & $0.002^{\mathrm{a}} \pm 0.292$ & $0.002^{\mathrm{c}} \pm 0.61$ \\
25 & $0.003^{\mathrm{b}} \pm 0.180$ & $0.003^{\mathrm{ab}} \pm 0.99$ & & $0.009^{\mathrm{b}} \pm 0.179$ & $0.001^{\mathrm{a}} \pm 0.80$ \\
50 & $0.005^{\mathrm{b}} \pm 0.178$ & $0.005^{\mathrm{a}} \pm 1.16$ & & $0.004^{\mathrm{b}} \pm 0.169$ & $0.001^{\mathrm{b}} \pm 0.68$ \\
75 & $0.002^{\mathrm{b}} \pm 0.186$ & $0.001^{\mathrm{a}} \pm 1.32$ & & $0.003^{\mathrm{c}} \pm 0.126$ & $0.003^{\mathrm{b}} \pm 0.76$ \\
100 & $0.004^{\mathrm{b}} \pm 0.153$ & $0.002^{\mathrm{c}} \pm 0.72$ & & $0.005^{\mathrm{c}} \pm 0.103$ & $0.002^{\mathrm{b}} \pm 0.73$
\end{tabular}

The data represent the mean of three replications \pm SD and similar upper case letters indicates no significant difference at $p<0.05$.

\subsection{Correlation analysis}

The analysis of correlation between MDA content and POD and SOD activity in shoot and root (at 1 and $5 \%$ levels) showed negative correlation coefficient between enzymes activities and MDA content. These findings indicate that POD and SOD involved in plants resistance to oxidative stress are induced by pyrene toxicity. Moreover, no correlation was seen between CAT activity and MDA content of the shoot and root of maize (Table 4).

Table 4: Statistical analysis for correlation between the activity of antioxidant enzyme and MDA content in the shoot and root of maize plant.

\begin{tabular}{lcccccccc}
\hline & SOD Root & SOD Shoot & POD Root & POD Shoot & CAT Root & CAT Shoot & MDA Root & MDA Shoot \\
\hline MDA Shoot & $0.685^{* *}-$ & $0.356^{\mathrm{ns}}$ & $0.287^{\mathrm{ns}}-$ & $0.574_{-}^{*}$ & $0.259^{\mathrm{ns}}$ & $0.047^{\mathrm{ns}}$ & $0.885^{* *}$ & 1 \\
MDA Root & $0.579^{*}$ & $0.352^{\mathrm{ns}}$ & $0.422^{\mathrm{ns}}-$ & $0.573^{*}-$ & $0.266^{\mathrm{ns}}-$ & $0.143^{\mathrm{ns}}$ & 1 & \\
CAT Shoot & $0.299^{\mathrm{ns}}$ & $0.04^{\mathrm{ns}}-$ & $-0.138^{\mathrm{ns}}$ & $0.052^{\mathrm{ns}}-$ & $0.106^{\mathrm{ns}}-$ & 1 & & \\
CAT Root & $0.002^{\mathrm{ns}}$ & $0.118^{\mathrm{ns}}$ & $0.722^{* *}$ & $0.235^{\mathrm{ns}}{ }_{-}$ & 1 & & & \\
POD Shoot & $0.372^{\mathrm{ns}}$ & $0.834^{* *}$ & $0.021^{\mathrm{ns}}$ & 1 & & & & \\
POD Root & $0.065^{\mathrm{ns}}{ }_{-}$ & $0.092^{\mathrm{ns}}$ & 1 & & & & & \\
SOD Shoot & $0.031^{\mathrm{ns}}-$ & 1 & & & & & \\
SOD Root & 1 & & & & & & & \\
\hline
\end{tabular}

Notes: **Correlation is significant at 0.01 levels, ${ }^{*}$ Correlation is significant at 0.05 levels, ${ }^{\mathrm{ns}}$ correlation is not significant. 


\section{DISCUSSION}

The results of this study showed that pyrene had a negative effect on the growth variables of maize plants. The results indicated that the growth variables were smaller by increasing of the concentrations of pyrene compared to the control plant. The reduction of the growth variables in the presence of PAHs had been reported previously in plants such as wheat (Tomar \& Jajoo, 2014; Salehi \& Deljoo, 2015), maize, pea seedlings (Kummerova et al., 2012), and Arabidopsis thaliana (L.) Heynh (Liu et al., 2009). Pyrene and possibly other compounds of this group by disrupting the development and function of the roots in the early stages of plant growth are playing an important role in mineral nutrition, will disrupt the growth and also decrease it. (Dupuy et al., 2016). The main mechanism could have been that there was increased sensitivity of maize to pyrene as indicated by high concentration of MDA with increasing pyrene concentration. This could have been caused by disruption in electron transportation and elicitation of ROS. Therefore, MDA accumulation resulting from oxidative stress and ROS accumulation was a reliable marker for determining of the negative effect of pyrene on the growth of maize plants.

For detoxification a plant would need a protective system equipped with enzymatic and non-enzymatic mechanisms for scavenging of reactive oxygen species (ROS) accumulated under oxidative stress (Alscher et al., 1997). Based on the results of the present study, CAT, POD, SOD activity, and anthocyanins content were increased by the different levels of pyrene leading to ROS detoxification and oxidative stress reduction. Therefore, these enzymes are important tools involved in the ROS detoxification and plant resistance to oxidative stress. Also, the analysis of correlation (Table 4) showed that there are a negative correlation between MDA content and POD and SOD activity in the shoot $\left(r^{2}=-0.574 \& r^{2}=-0.685\right.$, respectively $)$ and the root $\left(r^{2}=-0.573 \& r^{2}=-0.579\right.$, respectively) indicating the role of these enzymes in ROS detoxification and plant resistance to oxidative stress. Moreover, no correlation was found between CAT activity and MDA content of the shoot and the root of maize (Table 4). Similar results were reported for sunflower, alfalfa and wheat plants (Salehi-Lisar \& Deljoo, 2015).

Photosynthetic pigments content changed in a different way by pyrene concentrations. Accordingly, chlorophyll a and carotenoids contents were increased and chlorophyll b content decreased. High ROS levels can decline chlorophyll levels leading to photosynthesis decline. Generally, this is result from light harvesting complex protein in photosystem II drasticaldamage under stress conditions. The chlorophyll $b$ is a part of this protein complex,embedded in the chloroplast membrane and by the increasing of ROS levels within chloroplast its content is reduced by the oxidative stress. The destruction rate of chloroplast membrane is also increased. Thus, the destruction of protein complex will occur under stress and chlorophyll b level will be also decreased (Liu et al., 2009; Alberet \& Thornber, 1977).

Pyrene had significant influence on soluble sugar content $(p<0.05) .25$ and 50 ppm of pyrene effectively increased the soluble sugar content in the shoots, but the increase of pyrene in the roots decreased its content. The increased concentration in carbohydrate in shoots could be the result of higher concentration of anthocyanins and better photosynthesis. The higher concentration of anthocyanins in shoots of plants treated by pyrene may acts as a protective pigments for photosynthesis apparatus, finally leading to increase in the soluble sugar content. Reduced level of soluble sugars in roots may be due to the low requirement for photosynthetic materials due to the reduced growth of maize roots (Table 1). In addition, lower carbohydrate content in roots can be due to higher consumption of energy for resistance to pyrene toxicity. According to our results, higher accumulation and degradation rate of pyrene was occurring in maize roots (Houshani et al., 2019). Carbohydrates in plants, in addition to energy production, lead to the regulation of various gene expressions (Rolland et al., 2006) and may have antioxidant activity (Lang-Mladek et al., 2010).

\section{CONCLUSION}

According to the obtained results, similar to other PAHs, pyrene especially at higher concentrations had a negative effect on growth and chlorophyll content of Zea mays. Pyrene induced oxidative stress in maize as shown by MDA accumulation in the plant. POD and SOD as well as anthocyanins could be an important antioxidant system involved in detoxification of ROS and plant resistance to pyrene toxicity. Therefore, these findings supported this fact that pyrene toxicity induces oxidative stress in the maize plant and it also increases the antioxidant systems activity in order to moderating stress condition. However, the antioxidant system of maize was not strong enough to eliminate all produced ROS at high concentrations, thus this caused oxidative damage to the plant and decreased its growth variables. 


\section{REFERENCES}

Alberet, R.S., \& Thornber, J.P. (1977). Water stress effects on content and organization of chlorophyll in mesophyll and bundle sheath chloroplast of maize. Plant Physiology, 59, 351-353. https://doi.org/10.1104/pp.59.3.351

Alkio, M., Tabuchi, T.M., Wang, X. (2005). Stress responses to polycyclic aromatic hydrocarbons in Arabidopsis include growth inhibition and hypersensitive response-like symptoms. Journal Experimental Botany, 56, 2983-2994. https://doi.org/10.1093/jxb/eri295

Alscher, R.G., Donahue, J.L., Cramer, C.L. (1997). Reactive oxygen species and antioxidant: Relationships in green cells. Plant Physiology, 100, 224-233. https://doi.org/10.1111/j.13993054.1997.tb04778.x

Boominathan, R., \& Doran, P.M. (2002). Ni induced oxidative stress in root of the Ni hyper accumulator Alyssum bertoloni. New Phytologist, 156, 202-205. https://doi.org/10.1046/j.1469-8137.2002.00506.x

Binet, P., Portal, J.M., Leyval, C. (2000). Fate of polycyclic aromatic hydrocarbons (PAHs) in the rhizosphere and mycorrhizosphere of ryegrass. Plant and Soil, 227, 207-213. https://doi.org/10.1023/A:1026587418611

Bradford, M.M. (1976). A rapid and sensitive method for the quantization of microgram quantities of protein utilizing the principle of protein-dye binding. Analytical Biochemistry, 72(1), 248-254. https://doi.org/10.1016/0003-2697(76)90527-3

Branquinho, C., Brown, D.H., Catarino, F. (1997). The cellular location of $\mathrm{Cu}$ in lichens and its effects on membrane integrity and chlorophyll fluorescence. Environmental and Experimental Botany, 38, 165179. https://doi.org/10.1016/S0098-8472(97)000154

Chance, B., \& Mealy, A.C. (1955). Assay of catalases and peroxidases. Methods Enzymology, 11, 764755 . 6879(55)02300-8

Chang, C., Yang, M., Wen, H., Chern, J. (2002). Estimation of total flavonoid content in propolis by two complementary colorimetric methods. Journal of Food and Drug Analysis, 10, 178-182.

Chiang, P., Li, K.P., Hseu, T.M. (1996). Spectrochemical behavior of carcinogenic polycyclic aromatic hydrocarbons in biological systems. Part II: a theoretical rate model for $\mathrm{BaP}$ metabolism in living cells. Applied Spectroscopy,
50 , https://doi.org/10.1366/0003702963904782

Collins, C., Fryer, M., Grosso, A. (2006). Plant uptake of nonionic organic chemicals. Environmental Science and Technology, 40, 45-52. https://doi.org/10.1021/es0508166

Dupuy, J., Legliz, P., Vincent, Q., Zelko, I., Mustin, Ch., Ouvard, S., Sterckeman, T. (2016). Effect and localization of phenanthrene in maiz roots. Chemospher, 149, 130-136. https://doi.org/10.1016/j.chemosphere.2016.01.102

Dupuy, J., Ouvrard, S., Leglize, P., Sterckeman, T. (2015). Morphological and physiological responses of maize (Zea mays) exposed on sand contaminated by phenanthrene. Chemosphere, 124, 110-115. https://doi.org/10.1016/j.chemosphere.2014.11.051

Fuxing, K., Dongsheng, C., Yanzheng, G., Yi, Z. (2010). Distribution of polycyclic aromatic hydrocarbons in subcellular root tissues of ryegrass. BMC Plant Biology, 10, 210-216. https://doi.org/10.1186/1471-2229-10-210

Gao, Y., \& Zhu, L. (2004). Plant uptake, accumulation and translocation of phenanthrene and pyrene in soils. Chemosphere, 55, 1169-1178. https://doi.org/10.1016/j.chemosphere.2004.01.037

Gong, Z., Alef, A., Wilke, B., Li, P. (2007). Activated Carbon Adsorption of PAHs from Vegetable Oil Used in Soil Remediation. Journal of Hazardous Materials, $\quad$ 143, 372-378. https://doi.org/10.1016/j.jhazmat.2006.09.037

Hartmut, K. L. (1987). Chlorophylls and carotenoids: Pigments of photosynthetic biomembranes. In R. D. Lester Packer (Ed.), Methods in enzymology. New York, NY: Academic Press. pp: 350-382.

Houshani, M., Salehi-Lisar, S.Y., Motafakkerazad, R., Movafeghi, A. (2019). Uptake and distribution of phenanthrene and pyrene in roots and shoots of maize (Zea mays L.). Environmental Science and Pollution Research, Published online. https://doi.org/10.1007/s11356-019-04371-3

Hung, H., \& Mackay, D. (1997). A novel and simple model of the uptake of organic chemicals by vegetation from air and soil. Chemosphere, 35, 959-977. https://doi.org/10.1016/S00456535(97)00182-3

Khan, S., Aijun, L., Zhang, S., Hu, Q., Zhu, Y. (2008). Accumulation of polycyclic aromatic hydrocarbons and heavy metals in lettuce grown in the soils contaminated with long-term wastewater irrigation. 
Journal of Hazardous Materials, 152, 506-515. https://doi.org/10.1016/j.jhazmat.2007.07.014

Kochert, A. (1978). Carbohydrate determination by phenol-sulfuric acid method. In: J.A. Hellebust and J.S. Craige, Editors, Handbook of physiology and biochemical methods, Cambridge University Press, London, pp: 95-97.

Kosnar, Z., Mercl, F., Tlustos, P. (2018). Ability of natural attenuation and phytoremediation using maize (Zea mays L.) to decrease soil contents of polycyclic aromatic hydrocarbons (PAHs) derived from biomass fly ash in comparison with PAHsspiked soil. Ecotoxicology and Environmental Safety, 153, 16-22. https://doi.org/10.1016/j.ecoenv.2018.01.049

Kummerova, M., Zezulka, S., Babula, P., Vanova, L. (2013). Root response in Pisum sativum and Zea mays under fluoranthene stress: Morphological and anatomical traits. Chemosphere, 90, 665-673. https://doi.org/10.1016/j.chemosphere.2012.09.047

Kummerova, M., Zezulka, S., Vanova, L., Fiserova, H. (2012). Effect of organic pollutant treatment on the growth of pea and maize seedlings. Central European Journal Biology, 7(1), 159-166. https://doi.org/10.2478/s11535-011-0081-1

Lang-Mladek, C., Popova, O., Kiok, K., Berlinger, M., Rakic, B., Aufastez, W. (2010). Transgenerational inheritance and resetting of stressinduced loss of epigenetic gene silencing in Arabidopsis. Molecular Plant, 3, 594-602 https://doi.org/10.1093/mp/ssq014

Li, F., Zeng, X., Yang, J., Zhou, K., Zan, Q., Lei, A., Tam, N.F.Y. (2014). Contamination of polycyclic aromatic hydrocarbons (PAHs) in surface sediments and plants of Mangroveswamps in Shenzhen, China. Marine Pollution Bulletin, 85(2), 590-596.

https://doi.org/10.1016/j.marpolbul.2014.02.025.

Liao, Ch., Xu, W., Lu, G., Liang, X., Guo, Ch., Yang, Ch., Dang, Z. (2015). Accumulation of hydrocarbons by maize (Zea mays L.) in remediation of soils contaminated with crude oil. International Journal of Phytoremediation, 17, 693-700.

https://doi.org/10.1080/15226514.2014.964840

Liu, H., Weisman, D., Yuan-bei, Y., Cui, B., Huang, Y., Colon-Carmona, A., Wang, Z. (2009). An oxidative stress response to polycyclic aromatic hydrocarbon exposure is rapid and complex in Arabidopsis thaliana. Plant Science, 176(3), 375- 382. https://doi.org/10.1016/j.plantsci.2008.12.002
Lundstedt, S. (2003). Analysis of PAHs and their transformation products in contaminated soil and remedial processes. Solfjadern Offset AB.Umea University, pp:3-5.

Mita, S., Murano, N., Akaike, M., Nakamura, K. (1997). Mutants of Arabidopsis thaliana with pleiotropic effects on the expression of the gen for betaamylase and on the accumulation of anthocyanin that is inducible by sugars. Plant Journal, 11, 841851. https://doi.org/10.1046/j.1365313X.1997.11040841.x

Obinger, C., Maj, M., Nicholls, P., Loewen, P. (1997). Activity, peroxide compound formation, and hemed synthesis in Escherichia coli HPII catalase. Archives Biochemistry Biophysics, 342(1), 58-67. https://doi.org/10.1006/abbi.1997.9988

Rolland, F., Baena-Gonzalez, E., Sheen, J. (2006). Sugar sensing and signaling in plants: conserved and novel mechanisms. Annual Review of Plant Biology, 57, 675-709. https://doi.org/10.1146/annurev.arplant.57.032905. 105441

Salehi-Lisar, S.Y., \& Deljoo, S. (2015). Physiological effect of phenanthrene on Triticum aestivum L., Helianthus annus and Medicago sativa. EurAsian Journal BioSciences, 9, 29-37. https://doi.org/10.1080/23311932.2015.1020189

Tomar, R.S., \& Jajoo, A. (2014). Fluoranthene, a polycyclic aromatic hydrocarbon, inhibits light as well as dark reactions of photosynthesis in wheat (Triticum aestivum L.). Ecotoxicology and Environmental Safety, 109, 110-115. https://doi.org/10.1016/j.ecoenv.2014.08.009

Watts, A.W., Ballestero, T.P., Gardner, K.H. (2006). Uptake of polycyclic aromatic hydrocarbons (PAHs) in salt marsh plants Spartina alterniflora grown in contaminated sediments. Chemosphere, $62(8)$, 1253-1260. https://doi.org/10.1016/j.chemosphere.2005.07.006

Wilcke, W. (2000). Polycyclic Aromatic Hydrocarbons (PAHs) in soil. Journal of Plant Nutrition and Soil Science, $\quad 163$, https://doi.org/10.1002/15222624(200006)163:3<229::AIDJPLN229>3.0.CO;2-6

Wilson, S.C., \& Jones, K.C. (1993). Bioremediation of soil contaminated with polynuclear aromatic hydrocarbons (PAHs). Environmental Pollution, 81 , 229-249. https://doi.org/10.1016/02697491(93)90206-4

Winterbourn, C.C., Mc Grath, B.W., Carrell, R.W. (1976). Reactions involving superoxide and normal 
Growth and antioxidant system responses of maize (Zea mays L.) seedling to ... of pyrene in a controlled environment

unstable hemoglobins. Biochemical Journal, 155, 493-502. https://doi.org/10.1042/bj1550493

Xu, Sh.Y., Chen, Y.X., Wu, W.X., Zheng, Sh.J., Xue, Sh.G., Yang, Sh.Y., Peng, Y.J. (2007). Protein changes in response to pyrene stress in maize (Zea mays L.) leaves. Journal Integrative Plant Biology, 49(2), 187-19. https://doi.org/10.1111/j.17447909.2007.00284.x 